\title{
Improving the Design of Virtual Learning Environments from a Usability Study
}

\author{
Germania Rodriguez Morales ${ }^{1,2(1 \times)}$, Pablo Torres-Carrion ${ }^{1}$, \\ Jennifer Pérez ${ }^{2}$, and Luis Peñafiel ${ }^{1}$ \\ ${ }^{1}$ Universidad Técnica Particular de Loja, San Cayetano Alto, Loja, Ecuador \\ \{grrodriguez, pvtorres, Ifpenafiel\}@utpl .edu .ec \\ ${ }^{2}$ Universidad Politécnica de Madrid, Madrid, Spain \\ jenifer.perez@etsisi.upm.es
}

\begin{abstract}
Usability as an area of knowledge of Computer Science closest to the user, has seen enhance their interest and development in recent times, due to the diversity of devices and forms of interaction. At the same time, educational institutions, aware of the potential existing in new technologies, and the disruption caused, invest their resources in the implementation of virtual learning platforms. In this investment, they seek diversify in the tools that allow the development of new teaching strategies, which are ubiquitous and continuous, adaptable to the needs of the user. In this context, a usability study is carried out, sustained in the method of inquiry with the questionnaire technique, following the proposal of Ferreira \& Sanz in 2009, measuring the parameters of Satisfaction, Learning, Operability, Attractiveness, Content and Communication. The best results are obtained in the Learning and Content indicators, and with lower scores the Operability, highlighting in the latter the low value in the Accessibility and Availability indicators. According to the results obtained, a proposal for improvements is proposed, in order to achieve a greater degree of usability in the mentioned environment. Finally, these improvements are implemented in the case study, making a new evaluation of users in order to validate the improvements made.
\end{abstract}

Keywords: Usability $\cdot$ Higher education $\cdot$ LMS $\cdot$ Design

\section{Introduction}

Several of the human activities require the management of large amounts of information in relatively short times, as well as the constant decision making, to be quickly and efficiently allow the development and advancement of all types of entities around the world for the benefit of humanity. The highlight of this accelerated change is the migration of the various services to Inter-net; supported by technological platforms that eliminate spatial and temporal barriers allowing access to millions of users to the information they contain. One of the fields that since many years ago it has adopted as a strategic ally to new technologies, is the educational field, which through large platforms supports the teaching-learning process. 
Therefore, the need to develop computer applications centered on the user is evident. In this sense, usability has become a factor with a more important role even than the information architecture itself or content management and increasingly arouses greater interest in the community of developers, who emphasize rigorous processes of evaluation during and after development. Based on these aspects, the research aims to: a) Carry out a usability study of the UTPL Learning Management System (LMS) that was based on different parameters that allow identify the aspects that negatively affect the usability conditions of the platform; b) Formulate alternative solutions for the LMS platform to guarantee, favor and facilitate the teaching-learning process for teachers and students; c) Implement the improvement proposal in a test site to determine the feasibility of these being moved to the real operating environment.

The report begins with a general theoretical revision and state of the art on the Usability in higher education fields, with several LMS platforms, with greater emphasis on the MOODLE platform. It also analyzes emerging methodologies, considering the methods, techniques and parameters used by researchers in the area to carry out this type of evaluation. Next, the study conducted with the specific EVA of the UTPL is presented as a case study, from the model proposed by Ferreira and Sanz [1,2] at the Universidad de la Plata. Then, the proposal of improvement of conformity to the representative problems revealed during the evaluation is shared, with the purpose of reaching a greater degree of usability within the environment. At the end, its implementation is detailed in the Moodle 1.9 platform hosted on a test server.

\section{Usability}

\subsection{Theoretical Framework}

Usability "studies the essential characteristics that a software or computer application must have in order to guarantee easy access to any person regardless of the technology available, and the knowledge they have about the use of ICT [3]. Bevan [4] shares a fairly specific definition, explaining how the usability and acceptability of a system or product for a particular class of users that perform specific tasks in a specific environment, where ease of use affects performance and user satisfaction and acceptability affects whether the product is used or not". Torres-Carrión [5], explains the great coverage of Usability, which evolves as a sub-area of UX, with great consideration in the scientific field for the design of quality; explains in [6] hat the study of Usability depends not only on the interaction system, but on how it has been validated and what the objectives were, and in the educational field it also has as premise that the learning attributes will vary between people, and this variable extends its value if we also consider the context from which it is evaluated.

The International Organization for Standardization (ISO) has also been concerned with providing technical and scientific coverage to this area of science. In the general field of quality in the Software industry, the ISO/IEC 9126-1:2001 standard is presented, later revised in ISO/IEC 25010:2011 (updated to 2017), where the key quality factors are established, including among them usability, and it is defined as a subset of quality in use consisting of effectiveness, efficiency and satisfaction, for consistency with its 


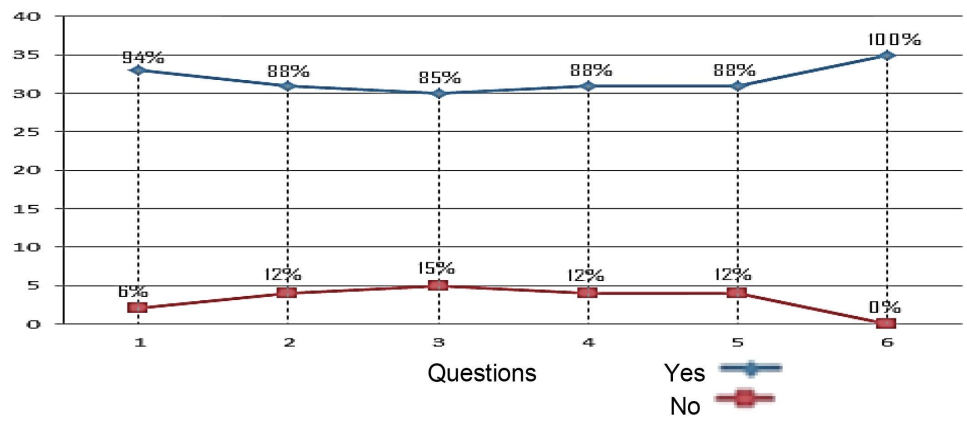

Fig. 4. Overall results of teachers functional tests

\section{Conclusions}

The development of this research work has allowed the acquisition of numerous knowledge and valuable experiences related to usability, a topic of interest at present in which humanity is virtually daily connected to the Internet to perform various activities. The objectives and level of knowledge of the users complicate the panorama of this technological environment. This is enough reason for the development of websites based on a user-centered methodology to be an alternative, a topic that has merited attention in various sectors. The study conducted on the subject has allowed to reach the following conclusions:

- A study case of evaluation of the usability of the Learning Management System LMS of the UTPL, which was carried out with the participation of real users of the platform (teachers and students) in order to obtain real results.

- A set of metrics and a scale was define that mark an initial diagnosis of usability for this type of platforms quantitatively, which was apply and validate in a study case.

- The improvement proposal was raised based on the analysis of the results obtained, the same ones that reveal those attributes that are located at an improvable or critical level, such as Communication, Personalization, Accessibility, Availability and Speed, which can be solved with a appropriate configuration of the platform and in the last two cases with the intervention of the UTPL through the cloud services project.

- The implementation allowed a post-study of the platform, determining that it offers a variety of alternatives to integrate sufficient and necessary functionalities to improve usability; this is corroborated by post-implementation tests that demonstrate its functionality with results above $80 \%$ and acceptance levels above $85 \%$.

The favorable results of the usability study do not depend only on the platform available in the institutional web portal. Although it is true that it is the main factor, in platforms with a high degree of parameterization, it also depends to a large extent on the policies established by the Educational Institution that adopts it, the administrators, the teachers and the students. In this way, the range of possibilities offered by the LMS 
can be adequately and converted into an efficient and effective environment that guarantees satisfaction in its use.

\section{References}

1. Ferreira Szpiniak A, Sanz CV (2009) Un modelo de evaluación de entornos virtuales de enseñanza y aprendizaje basado en la usabilidad. In: IV Congreso de Tecnología en Educación y Educación en Tecnología, pp 382-392

2. Ferreira Szpiniak A (2013) Diseño de un modelo de evaluación de entornos virtuales de enseñanza y aprendizaje basado en la usabilidad. https://postgrado.info.unlp.edu.ar/wpcontent/uploads/2017/11/2013_Ferreira_Szpiniak_Ariel.pdf

3. Alfonso Cuba IM (2012) Usabilidad en la Educación: Garantía de la calidad de la Educación Virtual. Editorial Universitaria, La Habana, Cuba

4. Bevan N (2001) International standards for HCI and usability. Int J Hum-Comput Stud 55:533-552

5. Torres-Carrión P (2018) Fundamentos de Interacción Humano-Computador. Texto-Guia. Universidad Técnica Particular de Loja, Loja-Ecuador

6. Torres-Carrión P (2017) Metodología HCI con análisis de emociones para personas con Síndrome de Down. Aplicación para procesos de aprendizaje con interacción gestual

7. International Organization for Standardization (2011) ISO/IEC 25010:2011(en) Systems and software engineering - Systems and software Quality Requirements and Evaluation (SQuaRE) - System and software quality models. https://www.iso.org/standard/35733.html

8. International Organization for Standardization (2016) ISO/DIS 9241-11.2 Ergonomics of human-system interaction - Part 11: usability: definitions and concepts. https:/www.iso.org/ obp/ui/\#iso:std:iso:9241:-11:dis:ed-2:v2:en

9. Fagalde P, Fontela C (2011) Artefactos de especificación de requerimientos de usabilidad. Universidad de Buenos Aires, Buenos Aires

10. Dumas J, Fox J (2007) Usability testing. In: The human-computer interaction handbook. CRC Press, pp 1129-1149

11. Dumas JS, Redish JC (1999) A practical guide to usability testing. Intellect Books, Exeter

12. Nielsen $\mathbf{J}$ (1994) Enhancing the explanatory power of usability heuristics. In: Proceedings of the SIGCHI conference on human factors in computing systems. ACM, New York, pp 152-158

13. John BE, Kieras DE (1996) Using GOMS for user interface design and evaluation: which technique? ACM Trans Comput Interact 3:287-319

14. Nielsen J (1993) Usability engineering. Morgan Kaufmann Publishers. Inc., San Francisco

15. Stake RE (1976) Evaluating educational programmes: the need and the response

16. Mtebe JS, Kissaka MM (2015) Heuristics for evaluating usability of learning management systems in Africa. In: Cunningham P, Cunningham M (eds) IST-Africa Conference, ISTAfrica 2015

17. Medina-Flores R, Morales-Gamboa R (2015) Usability evaluation by experts of a learning management system. Rev Iberoam Tecnol Del Aprendiz 10:197-203

18. Almarashdeh IA, Sahari N, Zin NAM (2011) Heuristic evaluation of distance learning management system interface. In: 2011 international conference on electrical engineering and informatics, ICEEI 2011, Bandung

19. Torres-Carrion P, Gonzalez-Gonzalez CS, Barba-Guamán R, Torres-Torres AC (2017) Experiencia Afectiva de Usuario (UAX): Modelo desde sensores biométricos en aula de clase con plataforma gamificada de Interacción Gestual. In: Actas del V Congreso Internacional de Videojuegos Educativos (CIVE 2017). Grupo ALFAS, Puerto de la Cruz - Tenerife - España 
20. Ulbricht VR, Berg CH, Fadel L, Quevedo SRP (2014) The emotion component on usability testing human computer interface of an inclusive learning management system. In: 1st international conference on learning and collaboration technologies, LCT 2014, Heraklion, Crete, pp 334-345

21. Pireva K, Imran AS, Dalipi F (2016) User behaviour analysis on LMS and MOOC. In: IEEE conference on e-learning, e-management and e-services, IC3e 2015, pp 21-26

22. Phongphaew N, Jiamsanguanwong A (2016) The usability evaluation concerning emotional responses of users on learning management system. In: 2016 6th international workshop on computer science and engineering, WCSE 2016, pp 43-48

23. Jiménes K, Pincay J, Villavicencio M, Jiménez A (2018) Looking for usability and functionality issues: a case study. In: Rocha Á, Guarda T (eds) International conference on information technology and systems, ICITS18, pp 948-958

24. Freire LL, Arezes PM, Campos JC (2012) A literature review about usability evaluation methods for e-learning platforms. Work 41:1038-1044

25. Nakamura, WT, De Oliveira, EHT, Conte T (2017) Usability and user experience evaluation of learning management systems a systematic mapping study. In: Proceedings of the 19th International Conference on Enterprise Information System, ICEIS 2017, pp 97-108. For CrossRef propouse it's available in http://www.scitepress.org/PublicationsDetail.aspx? $\mathrm{ID}=\mathrm{fMK} \mathrm{crDdaCvI}=\& \mathrm{t}=1$

26. Aydin B, Darwish MM, Selvi E (2016) State-of-the-art-matrix analysis for usability of learning management systems. In: 123rd ASEE annual conference and exposition

27. Pástor D, Jiménez J, Arcos G, Romero M, Urquizo L (2018) Design patterns for building online courses in a virtual learning environment. Ingeniare 26:157-171

28. Lai L-L, Lin S-Y (2017) An analysis for difficult tasks in e-learning course design. In: Nah FH, Tan CH (eds) 4th international conference on HCI in business, government and organizations, HCIBGO 2017, held as part of the 19th international conference on humancomputer interaction, HCI 2017, pp 171-180

29. Minović M, Štavljanin V, Milovanović M, Starčević D (2008) Usability issues of e-learning systems: case-study for moodle learning management system. In: Meersman R, Tari Z, Herrero P (eds) International conference on On the Move to Meaningful Internet Systems, OTM 2008 and held ADI 2008, AWeSoMe 2008, COMBEK 2008, EI2N 2008, IWSSA, MONET 2008, OnToContent 2008, QSI 2008, ORM 2008, PerSys 2008, RDDS 2008, SEMELS 2008 and SWWS 2008, pp 561-570

30. Harrati N, Bouchrika I, Tari A, Ladjailia A (2016) Exploring user satisfaction for e-learning systems via usage-based metrics and system usability scale analysis. Comput Hum Behav 61:463-471

31. Althobaiti MM, Mayhew P (2016) Assessing the usability of learning management system: user experience study. In: Vincenti G, Bucciero A, Vaz de Carvalho C (eds) 2nd international conference on e-learning, e-education, and online training, eLEOT 2015, pp 9-18

32. Kurata YB, Bano RMLP, Marcelo MCT (2018) Effectiveness of learning management system application in the learnability of tertiary students in an undergraduate engineering program in the Philippines. In: Andre T (ed) AHFE 2017 international conference on human factors in training, education, and learning sciences, 2017, pp 142-151

33. Banimahendra RD, Santoso HB (2018) Implementation and evaluation of LMS mobile application: scele mobile based on user-centered design. In: 2nd international conference on computing and applied informatics 2017, ICCAI 2017

34. Phongphaew N, Jiamsanguanwong A (2018) Usability evaluation on learning management system. In: Ahram T, Falcão C (eds) AHFE 2017 international conference on usability and user experience, 2017, pp 39-48 
35. Lalande N, Grewal R (2012) Blackboard vs. Desire2Learn: a system administrator's perspective on usability. In: 2012 international conference on education and e-Learning innovations, ICEELI 2012, Sousse

36. Okike EU, Morogosi M (2018) Measuring the usability probability of learning management software using logistic regression model. In: 2017 SAI computing conference 2017, pp 12171223

37. Karagiannis I, Satratzemi M (2017) Enhancing adaptivity in moodle: framework and evaluation study. In: Auer M, Guralnick D, Uhomoibhi J (eds) 19th international conference on interactive collaborative learning, ICL 2016, pp 575-589

38. Ifinedo P, Pyke J, Anwar A (2018) Business undergraduates' perceived use outcomes of Moodle in a blended learning environment: the roles of usability factors and external support. Telemat Inform 35:93-102

39. González de Felipe, AT (2009) Guía de apoyo para el uso de Moodle 1.9. 4. Usuario Profesor. Universidad de Oviedo, Oviedo 